\title{
Determinants Of Instructor's Influence On Selection Of A Major In An Integrated Introductory Business Course
}

\author{
Kathleen Simione, (E-mail: Kathleen.Simione@quinnipiac.edu), Quinnipiac University \\ David Cadden, (E-mail: David.Cadden@quinnipiac.edu), Quinnipiac University \\ Mark A Thompson, (E-mail: Mark.Thompson@quinnipiac.edu), Quinnipiac University \\ Anne Rich, (E-mail: richann@ccsu.edu), Central Connecticut State University
}

\begin{abstract}
Increasingly, as part of a desire to improve student understanding of the integrative nature of business, more and more schools are introducing interdisciplinary courses into the curriculum. These courses may also assist students with their choice of major. Generally, courses of this type are offered at the introductory level and may be structured in a variety of ways. Many questions still exist about the overall effectiveness of these courses with respect to teaching an understanding of integration, the appropriateness of alternative course designs, and how they might influence the selection of a major. Our institution has had such an Introductory Business Course for more than a decade. The course has always contained a process of continuous quality improvement .The course has evolved rather significantly during the last decade. One of its most recent and substantive changes has been to move from having multiple faculty members teaching each section to having each section taught by a single instructor. We felt that it was critical to examine the effectiveness of this change with regard to teaching, and also to see if the use of the single instructor model impacted student selection of a business major. The paper evaluates the effectiveness of faculty members to teach material outside their discipline. It also examines for the possible influence by instructors on selection of majors in the instructor's discipline in an introductory business course.
\end{abstract}

\section{INTRODUCTION}

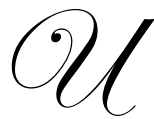

ndergraduate introduction to business courses have been initiated at many colleges and universities. Although varying in form, these courses generally serve to provide an introduction to business organizations highlighting the interrelationships among functional areas in business. The expectation with this type of integrated course, as part of an integrated curriculum, is to help prepare students to be "adaptive problem solvers" in a constantly changing business environment (Barsky, 1999). Companies expect that this will help students meet industry demand in a global business environment.

Increasingly integration across the business curriculum has been acknowledged as vital to students who must function in $21^{\text {st }}$ century organizations (Geiger and Dangerfield, 1996; LeClair, 1998; McKinney, 1998). Driving the move towards integration has been criticism that business schools have produced graduates who are too specialized and who lack the knowledge, methods and skills to make complex business decisions (Behrman and Levin 1984). The criticism implies that the traditional functional focus leaves students with little understanding of the interrelationships between business disciplines (DeMoranville, et al., 2000).

Porter (1997) advocated the move away from a functional focus noting the benefits of cross-functional integration of the business curriculum on life-long learning. Other benefits, as noted by Newell (1994), include development of effective and cognitive skills. Further motivation for a more integrative curriculum stems from pressure by the AACSB-International (Association to Advance Collegiate Schools of Business) to integrate the core areas of business and apply cross-functional approaches (AACSB standards). Integration, however, has not been 
limited to undergraduate programs. The University of Massachusetts at Lowell M.B.A. program replaced specialtydriven core courses with interdisciplinary courses taught by a team of professors (Lanza 1992).

\section{NOTE}

Full paper is available from author.

\section{REFERENCES}

1. Association to Advance Collegiate Schools of Business, Business Standards, Curriculum Content and Evaluation, St. Louis, 2002.

2. $\quad$ Barsky, N. (1999). Education, Pennsylvania CPA Journal, Philadelphia, Volume 30, (1), 17-47.

3. Behrman, J.N. and Levin, R.I. (1984). Are Business Schools Doing Their Job?, Harvard Business Review, Volume 62, (1), 140-147.

4. Berger, Mark C. (1988). Predicted Future Earnings and Choice of College Major, Industrial and Labor Relations Review, Volume 41, (3), 418-429.

5. Chen, C.C., Jones, K.T. and McIntyre, D.D. (2004). Examining Minorities Perceptions of Accounting, The CPA Journal. Volume 74, (8), 64-66.

6. Cohen, J. and Hanno, D.M. (1993). An Analysis of Underlying Constructs Affecting the Choice of Accounting as a Major, Issues in Accounting Education, Volume 6, (2), 219-231.

7. DeMoranville, C., Aurand, T.W., and G.L. Gordan (2000). The Delivery of an Undergraduate Crossfunctional, Business Principles Program: One University’s continuing Journey, Marketing Education Review, Volume 10, (3), 29-41.

8. Fanno, W. and Cole, R. Lee C. (1999). Survey of Early Leavers: Implications for Recruitment in Agricultural Education, Proceedings of the $26^{\text {th }}$ Annual National Agricultural Education Research Conference.

9. $\quad$ Felton, S., Buhr, N. and M. N. (1994). Factors Influencing the Business Student's Choice of a Career in Chartered Accountancy, Issues in Accounting Education, Volume 9, (1), 131-138.

10. Geiger, J. J., and Dangerfield, B. J. (1996). An Analysis of Integrated Curriculum Models in U. S. Colleges and Businesses, Proceedings of the Decision Sciences Institute.

11. Gist, W. E., Goedde, H. and Ward, B. H. (1996). The Influence of Mathematical Skills on Minority Student Performance in Principles of Accounting, Issues in Accounting Education, Volume 11, (1), 49-50.

12. Hoffman, J.L. and Lowitzki, K.E. (2005). Predicting College Success with High School Grades and Test Scores: Limitations for Minority Students, Review of Higher Education, Volume 28, (4), 255-475.

13. Jang, Soomyung, Two Essays on Work and Education, Dissertation, July 2001.

14. Jones, Mark C. (2006). High Stakes Teaching: The First Course in Geography, The Journal of Geography, Volume 105, (2), 87-89.

15. Kim, D. and Markham, F. S. (2002). Why Students Pursue the Business Degree: A Comparison of Business Majors Across Universities, The Journal of Education for Business, Volume 78, (1), $28-32$.

16. Lanza, J. (1992). UMass/Lowell Has New Business Approach, The Boston Business Journal, Volume 12, (41), 213-222.

17. LeClair, D. (1998). Economics of Organization and Management: An Integrative Course Proposal, Journal of Management Education, Volume 22, (4), 509-525.

18. Long, H.E. and Coldren, J.T., (2006). Interpersonal Influences in Large Lecture-Based Classes: A Socioinstructional Perspective, College Teaching, Volume 54, (2), 237-243.

19. Lyson, Thomas A. (1984). Sex Differences in the Choice of a Male or Female Career Line: An Analysis of Background Characteristics and Work Values, Work and Occupations, Volume 11, (2), 131-147.

20. Malgwi, C.A., Howe, M.A., and Burnaby, P.A. (2005). Influences on Students' Choice of College Major, Journal of Education for Business, Volume 80, (5), 275-282.

21. Mauldin, S., Crain, J.L., and P.H. M. (2000). The Accounting Principles Instructor's Influence on Students' Decisions to Major in Accounting, Journal of Education for Business, Volume 75, (3), 142-148.

22. McKinney, Earl, (1998). The One School Roomhouse: An Information and Learning Approach to Curriculum Integration, Journal of Management Education, Volume 22, (5), 618-636. 
23. Newell, W. H., Designing Interdisciplinary Courses, New Directions for Teaching and Learning, Volume 58, 22-29.

24. Paolillo, J.G.P. and Estes, R. W. (1982). An Empirical Analysis of Career Choice Among Accountants, Attorneys, Engineers, and Physicians, The Accounting Review, Volume 57, (4), 785-793.

25. Pappu, R. (2004). Why Do Undergraduate Majors Select Marketing as a Business Major? Evidence from Australia, Journal of Marketing Education, Volume 26, Issue 1, 31-41.

26. Porter, L. (1997). A Decade of Change in the Business School: From Complacency to Tomorrow, Selections, Volume 13, (2), 1-8.

27. Pritchard, R.E., Potter, G.C., Saccucci, M.S. (2004). The Selection of a Business Major: Elements Influencing Student Choice and Implications for Outcomes Assessment, Journal of Education for Business, Volume 79, (3), 152-156

28. Schlee, Regina P. (2005). Social Styles of Students and professors: Do Students' Social Styles Influence their Preferences for Professors?, Journal of Marketing Education, Volume 27, (2), 130-143.

29. Smith, Gene (2005). Reversing the Decreasing Trend of Students Majoring in Accounting, Managerial Auditing Journal, Volume 20, Issue 8/9, 936-944.

30. Wildman, M. and Torres, R. (1999). Selecting a Major in Agriculture: Implications for Recruitment in Agricultural Education, Proceedings of the $26^{\text {th }}$ Annual National Agricultural Education Research Conference.

31. Worthington, A. and Higgs, H. (2004). Factors Explaining the Choice of an Economics Major: The Role of Student Characteristics, Personality and Perceptions, International Journal of Social Economics, Volume 31, (5/6), 593-604.

32. Zwick, R. and Sklar, J.C. (2005). Predicting College Grades and Degree Completion Using High School Grades and SAT Scores: The Role of Student Ethnicity and First Language, American Educational Research Journal. Fall 2005, Vol.42, (3), 439-465. 